\title{
Slash-and-Burn Practices Decrease Arbuscular Mycorrhizal Fungi Abundance in Soil and the Roots of Didierea madagascariensis in the Dry Tropical Forest of Madagascar
}

\author{
Alícia Donnellan Barraclough 1,2,*(D) and Pål Axel Olsson 1 \\ 1 Biodiversity, Department of Biology, Ecology Building, Lund University, SE-223 62 Lund, Sweden; \\ pal_axel.olsson@biol.lu.se \\ 2 Institute for Applied Ecology, Auckland University of Technology, Auckland 1010, New Zealand \\ * Correspondence: adonnell@aut.ac.nz
}

Received: 27 August 2018; Accepted: 26 September 2018; Published: 1 October 2018

\begin{abstract}
Deforestation and the use of fire to clear land have drastic effects on ecosystem functioning and compromise essential ecosystem services, especially in low-income tropical countries such as Madagascar. We evaluated the effects of local slash-and-burn practices on soil nutrients and arbuscular mycorrhizal (AM) fungi abundance in a southwestern Madagascar forest. Nine sampling plot pairs were established along the border of a reserve within the Fiherenana-Manombo (pk-32) complex, where soil and seedling root samples of the endemic tree Didierea madagascariensis were taken. We analysed soil extractable $\mathrm{PO}_{4}{ }^{3-}, \mathrm{NH}_{4}{ }^{+}$, and $\mathrm{NO}_{3}{ }^{-}$as well as total soil carbon and nitrogen. We analysed AM fungal abundance in soil and roots through fatty acid marker analysis (NLFA and PLFA 16:1 $\omega 5$ ), spore extraction, and root staining. Slash-and-burn caused an increase in $\mathrm{pH}$ and doubled the plant available nutrients (from 7.4 to $13.1 \mu \mathrm{g} \mathrm{PO}_{4}{ }^{3-} \mathrm{g}^{-1}$ and from 6.9 to $13.2 \mu \mathrm{g} \mathrm{NO}_{3}{ }^{-} \mathrm{g}^{-1}$ ). Total $\mathrm{C}$ and total $\mathrm{N}$ increased in deforested soil, from $0.6 \%$ to $0.84 \%$ and from $0.06 \%$ to $0.08 \%$, respectively. There was a significant decline in AM fungi abundance in soil, with a decrease in soil NLFA 16:1 w5 from 0.2 to $0.12 \mathrm{nmol} / \mathrm{g}$. AM fungi abundance in D. madagascariensis roots was also negatively affected and colonization decreased from $27.7 \%$ to $16.9 \%$ and NLFA $16: 1 \omega 5$ decreased from 75.7 to $19 \mathrm{nmol} / \mathrm{g}$. Together with hyphal network disruption, increased nutrient availability caused by burning is proposed as an explanation behind AM decline in soil and roots of D. madagascariensis. This is the first study to report the effects of slash-and-burn on AM symbiosis in Madagascar's dry forests, with likely implications for other tropical and subtropical dryland forests worldwide where slash-and-burn is practiced.
\end{abstract}

Keywords: slash-and-burn; fire; deforestation; soil chemistry; NLFA; PLFA; mycorrhizal symbiosis; Didierea; endemic; Madagascar; arbuscular mycorrhiza

\section{Introduction}

The severe deforestation affecting Madagascar for the past 100 years is becoming increasingly recognized, with less than $10 \%$ of its primary forest cover remaining (Harper et al., 2007 [1]). This decline is caused by high human population growth coupled with forest exploitation, which seriously threatens endemic plant species (Goodman and Benstead, 2003 [2]). The Spiny Forest, a dry primary forest typical of southwest Madagascar, has been identified as a global conservation priority (Seddon et al., 2000 [3]) because of its high rate of endemism, reaching almost $90 \%$ of vascular plant species (Callmander, 2011 [4]). This centre of endemism occupies approximately 44,000 km², but less than 3\% of this area is protected (Wilmé, 2006 [5]). Studies have shown that the southwestern 
Spiny Forest of Madagascar has a similar function and behaviour to other dry forests of the world (e.g., Mexico), with similar basic ecosystem characteristics such as plant biomass, nutrient concentration, and nutrient storage (Raherison and Grouzis, 2005 [6]). Slash-and-burn maize agriculture and timber foraging for charcoal production have been defined as the driving factors for deforestation in this region (Casse et al., 2004 [7]). Despite its global importance, the Spiny Forest has received little specific ecological research and it has been identified as a highly understudied at-risk region, with most studies having taken place in areas with very different soil and hydrology (e.g., the Mahafaly calcareous plateau (SuLaMa project) or the Mikea forest) (Seddon, 2000 [3]; Randriambanona 2018 [8])).

Deforestation practices in the tropics using fire are known to affect important soil properties and processes, such as soil chemical and physical parameters, nutrient cycling (Giardina 2000a [9]; Beliveau 2015 [10]; Ribeiro Filho 2015 [11]), and carbon dynamics (Don 2011 [12]; Beliveau 2015 [10]; Mukul 2016 [13]), and to cause alterations in the soil microbial community (Bellgard, 1994 [14] Rodrigues 2012 [15]; García de León 2018 [16]). Slash-and-burn practices used in Madagascar (hatsake) are known to cause soil erosion, soil compaction, and long-term nutrient loss through volatilization and leaching (Styger 2009 [17]; Leprun 2009 [18]; Gay-des-Combes 2017 [19]). These changes can lead to further changes in ecosystem functions and services, such as loss of soil fertility, forest regeneration, or sustainable agroforestry use (Runyan, 2012 [20]; Gay-des-Combes 2017 [19]). The effects of fire disturbance can be particularly strong in dry and extreme habitats of the world, such as southwest Madagascar, and natural vegetation succession on cleared land is not thought to revert towards mature forests (Leprun 2009 [18]). However, very little is known about how the soil and the microbial community of the dry southwestern forests respond to slash-and-burn practices, as they are fundamentally different in nature from the more extensively studied eastern humid rainforest soils (Styger 2007 [21]; Raharimalala 2012 [22]).

Within the soil microbial community, the importance of mycorrhiza for forest ecology is evident. Over $75 \%$ of vascular plant species live in symbiosis with arbuscular mycorrhizal (AM) fungi (Newman and Reddell, 1987 [23]; Smith and Read, 2008 [24]). These provide significant advantages to their hosts, such as increased nutrient absorption (mainly phosphorous), resistance to water stress, and improved edaphic adaptation (Johnson, 2010 [25]). The role of AM is not limited to the individual plant but also influences the whole plant community, intervening in community composition, diversity, and succession (Van der Heijden, 1998 [26]; García de León 2018 [16]). Lastly, the presence of AM fungi in soil influences the whole microbial community both directly and indirectly, affects soil structure, and is thought to make a large contribution to soil carbon pools in tropical forests (Rillig, 2001, 2004 [26,27]). AM fungi abundance is affected by disturbance and land use changes in tropical ecosystems (Johnson and Wedin, 1997 [28]; Muchane et al., 2012 [29]). For this reason, AM are considered as a factor of great importance in assessing the effects of deforestation and disturbance and have been taken into account in the design and implementation of successful reforestation projects (Wubet et al., 2003 [30]; García de León 2018 [16]). The effects of slash-and-burn on AM fungal abundance and diversity in soil have received little or no attention in the whole of Madagascar, with most studies focusing on changes in land use in general (Tedersoo, 2011 [31]). Considering the importance of fungal symbiosis in plant growth and successional processes occurring on disturbed land (Van der Heijden, 1998 [26]), understanding the effect of slash-and-burn on AM status of plants and soils in southern Malagasy systems is vital.

Lastly, most studies of mycorrhizal fungi in Madagascar have taken place in the humid eastern part of the island, with the mycorrhizal status of native eastern trees and orchids only recently being assessed (Ducousso et al., 2008 [32]; Yokoya, 2015 [33]). To date, the mycorrhizal status of plant species endemic to the southwest has never been described, and given the high endemic value of this vegetation type, even within the island (50\% of species are unique to this ecotype), this represents an important knowledge gap. Didierea madagascariensis Baillon, Henri Ernest (1880) is the phytosociological key species of the study area and belongs to the Didiereaceae (Caryophyllales), a family endemic to the region. The Caryophyllales order is typically nonmycorrhizal but some of its species are known to present important 
mycorrhizal colonization, for example, in extremely saline or arid habitats. So far, no efforts have been made to assess the mycorrhizal status of any of the Didiereaceae family members ([34]).

In this project, we studied the effects of traditional slash-and-burn practices along the border of a protected area of the dry forest of southwest Madagascar. Our aims were to establish a preliminary assessment of the effects of slash-and-burn disturbance levels on important soil properties and AM fungi abundance in soil through soil chemistry analysis, spore extraction, and signature fatty acid analysis-a tool which has proved useful for the estimation of AMF (Arbuscular mycorrhizal fungi) biomass in soils (Olsson, 1999 [35]). In addition, the effects of deforestation on the presence of AMF in the roots of the key tree species, $D$. madagascariensis, was assessed both through traditional root staining and fatty acid analysis. We hypothesized that slash-and-burn would negatively affect AMF abundance in soil (fatty acid markers and spores) and roots (fatty acid markers and colonization) when compared to original undisturbed forests. Additionally, we hypothesized that changes in AM symbiosis in D. madagascariensis may be partly explained by changes in soil nutrient parameters caused by deforestation.

\section{Materials and Methods}

\subsection{Study Area}

This study was conducted in an area of Madagascar's Spiny Forest eco-region, located between the Fiherenana and Manombo Rivers, in the province of Tulear. This region has a dry tropical climate, where average rainfall is $300 \mathrm{~mm}$ per year, of which $85 \%$ falls between November and March. The mean annual temperature is $26^{\circ} \mathrm{C}$, with a peak of $42{ }^{\circ} \mathrm{C}$ in December (Salomon, 1987 [36]).

The region where the study site is located is known as the Fiherenana-Manombo complex, or the pk-32. This region is sometimes called "South Mikea" as it is geologically similar to the neighbouring Mikea forest. Both areas have similar forest stands that grow on unconsolidated arid red sandy entisols and are clearly differentiated from the spiny thickets on the dryer calcareous plateau south of Tulear (Seddon 2000 [3]). However, plant communities in the two areas differ significantly. In the pk-32 study area, the vegetation type has been identified as "dry spiny forest on de-calcified red sand", with the phytosociological key species D. madagascariensis (Cabanis and Chabouis 1987 [37]). The sampling area was located in proximity to the village of Mangily in the rural commune of Belalanda. The village is a fishing community and a small tourist coastal destination of approximately 7000 inhabitants in 2012. Agriculture is of small economic importance. Sampling sites were located on the 2-km border of the Reniala Private Reserve $\left(23^{\circ} 12^{\prime} 53^{\prime \prime} \mathrm{S}, 43^{\circ} 61^{\prime} 98^{\prime \prime} \mathrm{E}\right)$, which is privately owned land that locals are not allowed to enter. The forest is characterized by a lack of an herbaceous layer, where understory vegetation consists of shrub species of Combretum, Chadsia, and Croton, and has an arboreal stratum that includes species of Delonix, Givotia, Euphorbia, Pachypodium, and Commiphora.

The deforested areas sampled outside the border had been selectively logged by locals (all large and valued timber for construction and coal production) and then cleared with the use of fire until only remnant vegetation was present. The land was then fenced with a barrier and used intermittently for wood and medicinal plant collection. According to local knowledge, burning had occurred within a period of $0-5$ years prior to sampling, with areas furthest from the village burned more recently than areas close to the village-although areas closest to the village were more severely burned and occasional burning still occurred intermittently to stop the spread of vegetation. The deforested land retained a few forest tree specimens of D. madagascariensis, Givotia madagascariensis, Delonix sp., Adansonia sp., and the shrub Securinega perrieri. No land cultivation had taken place prior to sampling.

\subsection{Field Sampling}

During the first weeks of the rainy season in January 2012, nine 100-m transects were established perpendicular to the border of the forested area, each between 100 and $200 \mathrm{~m}$ apart. Transect positions followed the road leading away from the town of Mangily into the forest, with $a$ being the transect closest to the town (1-km distance) and $i$ being the furthest (2.5- $\mathrm{km}$ distance) (Figure 1). Sampling 
was performed in this way in order to asses any effect of proximity to the town on results, including distance from town as a fixed factor in posterior analysis. Half of each transect was located inside the border of the forest reserve and half in deforested plots outside the border. Throughout the transects, vegetation was examined in order to determine the species found in both forest and deforested plots. D. madagascariensis seedlings were the only species present in both areas with a viable sampling size. For each of the nine transects, a paired design was implemented: in each area (forested/deforested), transects were examined for one to three $D$. madagascariensis seedlings of approximately the same age (1-2 years) and size $(15-20 \mathrm{~cm})$, which were then pooled into one replicate sample per area (forested/deforested) by performing total harvest of identified individuals. Soil surrounding each plant sample was collected to a depth of $20 \mathrm{~cm}(0-20 \mathrm{~cm})$ and pooled. This design yielded a total of nine replicates per area (forested/deforested). Root and soil samples were dried at $40{ }^{\circ} \mathrm{C}$ and stored dry until analysis.

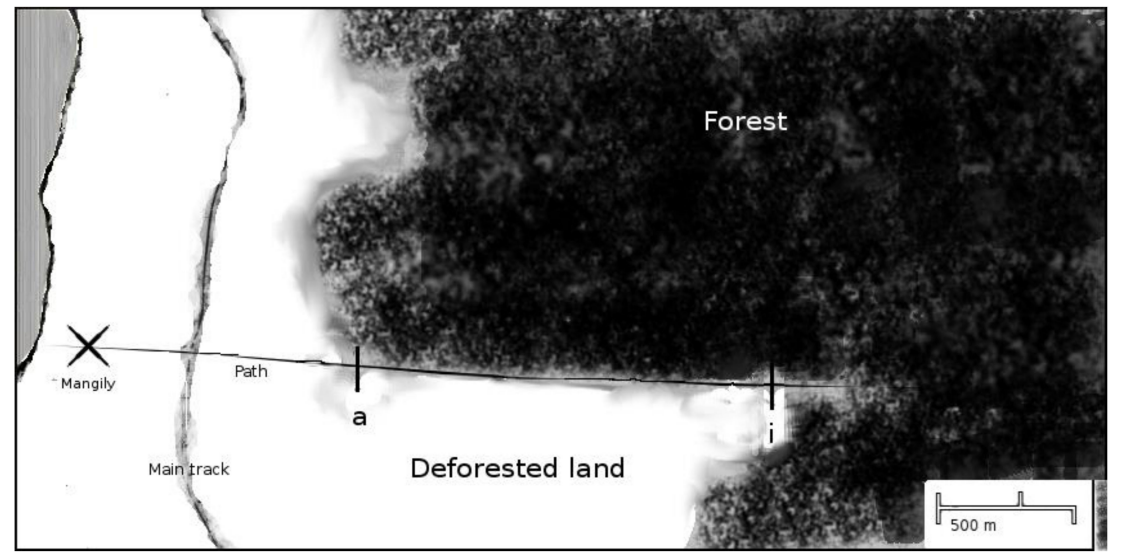

Figure 1. The sampling site situated $1 \mathrm{~km}$ from the coast town of Mangily (indicated by a cross). Dark areas indicate intact forest and light areas indicate burned deforested areas. The vertical line indicates the position of the first sampling pair transect (a) and the blue line indicates the position of the last transect (i).

\subsection{Soil Chemistry}

Extractable phosphate was analysed using flow injection analysis after $2 \mathrm{~h}$ of extraction following two different methods: first, according to Bray and Kurtz (1945 [38]), by using $100 \mathrm{~mL}$ of Bray-1 solution to $5 \mathrm{~g}$ of soil, and second, by using $100 \mathrm{~mL}$ of $0.05 \mathrm{M} \mathrm{Na}_{2} \mathrm{SO}_{4}$ and $0.02 \mathrm{M} \mathrm{NaF}$ solution to $20 \mathrm{~g}$ soil (NaFS). Extractable $\mathrm{N}\left(\mathrm{NH}_{4}{ }^{+}\right.$and $\left.\mathrm{NO}_{3}{ }^{-}\right)$was determined by flow injection analysis after $2 \mathrm{~h}$ of extraction in $0.2 \mathrm{M}$ $\mathrm{BCl}_{2}$. $\mathrm{pH}$ was measured electrometrically in the supernatant of a $2-\mathrm{h}$ water extraction in a rotator. Total carbon and total nitrogen were determined with a C:N Variomax element analyser.

\subsection{Lipid Extraction and Analysis}

To estimate AM fungal biomass, both soil and roots were subjected to phospholipid-derived fatty acid (PLFA) analysis according to Van Aarle and Olsson (2003 [39]). For each replicate, $5 \mathrm{~g}$ of dried soil was used, and an approximately 30-mg sample of dry roots was crushed with small pestles in Eppendorf tubes. Each sample was mixed with $10 \mathrm{~mL}$ of Blight and Dyer (1959 [40]) mixture (B\&D) containing chloroform, methanol, and citrate buffer (1:2:0.8, v/v/v, pH 4) and left to extract for $2 \mathrm{~h}$ at room temperate. The phases were separated by adding citrate buffer chloroform to the lipids, which were then separated on prepacked silica columns (100-mg sorbent mass, Varian Medical systems, Palo Alto, CA, USA). Neutral lipids were eluted and collected with $1.5 \mathrm{~mL}$ chloroform, glycolipids with $6 \mathrm{~mL}$ acetone (discarded), and phospholipids with $1.5 \mathrm{~mL}$ methanol.

Transesterification of lipids to free fatty acid methyl esters was performed by addition of $1 \mathrm{~mL}$ of $\mathrm{KOH}$ in methanol and a $15-\mathrm{min}$ incubation at $37^{\circ} \mathrm{C}$. Identification and quantification of phospholipid and neutral lipid fatty acids were performed using gas chromatography (Hewlett Packard 5890, 
50m HPS capillary column, Palo Alto, CA, USA), with $\mathrm{H}_{2}$ as the carrier gas, by identifying peaks and comparing retention times relative to the internal standard fatty acid 19:0.

Fatty acids used for quantifying soil AM fungi mycelium and root colonization were NLFA 16:1 $\omega 5$ and PLFA 16:1 $\omega 5$. These are common in AM fungal storage lipids and membranes, respectively, but the specificity of PLFA 16:1w5 is low due to high background levels originating from bacteria (Olsson 1999 [35], Van Aarle and Olsson 2003 [39]).

\subsection{Microscopic Analysis of Root Colonization}

For each plant replicate, the root system was partitioned and a representative root sample was used for determining the percentage of AM fungal colonization. Roots were washed in water, cut into 1-3-cm pieces, and stained according to a modified version of the method described by Phillips \& Hayman (1970 [41]). Thin and thick roots were cleared in $10 \% \mathrm{KOH}$ at $60{ }^{\circ} \mathrm{C}$ for 1 and 2 days, respectively. Subsequently they were bleached in $30 \% \mathrm{H}_{2} \mathrm{O}_{2}$ and then acidified for $10 \mathrm{~min}$ in $1 \mathrm{M} \mathrm{HCl}$ before staining with Trypan blue in $0.1 \%$ lactoglycerol overnight. Following one day of destaining in glycerol, thin and thick root pieces were mounted on separate slides. A visual count of the presence of AM fungal structures (arbuscules, vesicles, coils, and hyphae) was performed following the line intersect method of McGonigle et al. (1990 [42]) by evaluating approximately 50 intersections per slide (thin and thick roots) using a compound microscope.

\subsection{Spore Extraction and Analysis}

Spore extraction was performed according to the wet-sieving and sucrose-centrifugation method (Mckenney 1987 [43]) as follows. Soil (30 g) was thoroughly washed and the soil-water mixture was passed successively through a stack of sieves of 1000-, 250-, 125-, and 50- $\mu \mathrm{m}$ mesh size. The sieving from the three sieves with the smallest mesh size was added separately to water and centrifuged at $2000 \mathrm{rpm}$ for $8 \mathrm{~min}$ prior to the resuspension of the pellet in a 50\% sucrose solution and a second centrifugation for $4 \mathrm{~min}$. The supernatant was washed on a $50-\mu \mathrm{m}$ sieve before vacuum filtration. Spores were examined on filter paper in Petri dishes. Spore count was performed for estimating spore densities (spore/100 g) for each of the three size fractions (Class A 250-1000 $\mu \mathrm{m}$, Class B 125-250 $\mu \mathrm{m}$, Class C $50-125 \mu \mathrm{m}$ ) and total spore density was calculated as the sum of the three fractions (spore $/ 100 \mathrm{~g}$ ).

\subsection{Statistical Analysis}

All data were checked for the assumption of normality with residual plots and the Shapiro-Wilk test on raw data and residuals. The assumption of equality of variances was tested with Levene's test (lawstat package). When assumptions were not met, data were submitted to either logarithmic or square root transformations. All soil chemistry and AM fungus variables were independently tested for differences between areas with the Student's paired $t$-test determined by transect location. The nonparametric Mann-Whitney U test was applied when conditions of normality were not met in either transformed or untransformed data. Fully orthogonal Spearman rank correlations were performed to assess the relationships between AM fungus variables and soil properties. Linear regression analysis was employed to identify the relationship between transect distance from the town and extractable nutrients. Statistical analysis and all graphs were performed with the statistical program R Studio (R Core Team 2017 [44]).

\section{Results}

\subsection{Soil Chemistry}

Soil $\mathrm{pH}$ was significantly higher in burned deforested than in forested areas $(\mathrm{t}=4.11, \mathrm{df}=7$, $p \leq 0.01$ ) (Table 1) and showed a negative correlation with distance from the town in deforested areas $\left(\mathrm{y}=-0.0004 \mathrm{x}+7.9 R^{2}=0.70, p \leq 0.05\right)$. 
Total $\mathrm{N}$ was significantly higher in burned deforested areas $(\mathrm{t}=2.61, \mathrm{df}=8, p \leq 0.05)$. Deforested areas showed also significantly higher levels of total carbon $(\mathrm{t}=2.64, \mathrm{df}=8, p \leq 0.05)$. C:N ratio tended to be higher in deforested areas but this was not significant $(\mathrm{t}=0.88, \mathrm{df}=8, p$-value $=0.40)($ Table 1$)$.

The paired $t$-test showed that $\mathrm{NO}_{3}{ }^{-}$was higher in burned deforested areas $(\mathrm{t}=5.22, \mathrm{df}=8$, $p \leq 0.001)$. However, no significant differences were observed in $\mathrm{NH}_{4}{ }^{+}(\mathrm{t}=1.14, \mathrm{df}=8, p$-value $=0.29)$ (Table 1). $\mathrm{NO}_{3}{ }^{-}$showed a strong negative linear regression with the distance from the town (Figure 2) and this relationship was stronger in deforested areas. Extractable phosphate as revealed by both Bray-1 and NaFS extraction showed significant differences between areas when analysed with paired $t$-tests (for Bray-1: $\mathrm{t}=4.65, \mathrm{df}=8, p \leq 0.001$; for NaFS: $\mathrm{t}=4.71, \mathrm{df}=8, p \leq 0.001$ ), being twice as high in burned deforested than in forested areas (Table 1). Phosphate levels also showed a negative linear regression with distance from the town. The regression relationship was stronger in burned deforested areas than in forested areas (Figure 2a).

Table 1. Summary of mean values and standard deviations for measured parameters in burned deforested and nonburned forested areas. Different letters indicate significance at $p$-value $<0.05$ from a paired $t$-test or Mann-Whitney $\mathrm{U}$ test.

\begin{tabular}{ccc}
\hline Parameter & Forest & Burned \\
\hline $\mathrm{pH}$ & $7.02 \pm 0.21^{\mathrm{a}}$ & $7.25 \pm 0.19^{\mathrm{b}}$ \\
Phosphate-Bray $(\mu \mathrm{g} / \mathrm{g})$ & $7.40 \pm 3.1^{\mathrm{a}}$ & $13.1 \pm 4.67^{\mathrm{b}}$ \\
Phosphate-NaFS $(\mu \mathrm{g} / \mathrm{g})$ & $1.01 \pm 0.56^{\mathrm{a}}$ & $2.05 \pm 0.9^{\mathrm{b}}$ \\
$\mathrm{NH}_{4}(\mu \mathrm{g} / \mathrm{g})$ & $2.14 \pm 0.32^{\mathrm{a}}$ & $2.00 \pm 0.55^{\mathrm{a}}$ \\
$\mathrm{NO}_{2}, \mathrm{NO}_{3}(\mu \mathrm{g} / \mathrm{g})$ & $6.96 \pm 4.8^{\mathrm{a}}$ & $13.2 \pm 7.51^{\mathrm{b}}$ \\
$\mathrm{Total}_{\mathrm{N}}(\mu \mathrm{g} / \mathrm{g})$ & $692 \pm 233^{\mathrm{a}}$ & $831 \pm 224^{\mathrm{b}}$ \\
Total C $(\mathrm{mg} / \mathrm{g})$ & $6.63 \pm 2.28^{\mathrm{a}}$ & $8.42 \pm 2.99^{\mathrm{b}}$ \\
$\mathrm{C}: \mathrm{N}$ Ratio & $9.60 \pm 0.90^{\mathrm{a}}$ & $9.95 \pm 0.92^{\mathrm{a}}$ \\
\hline \multicolumn{3}{c}{}
\end{tabular}

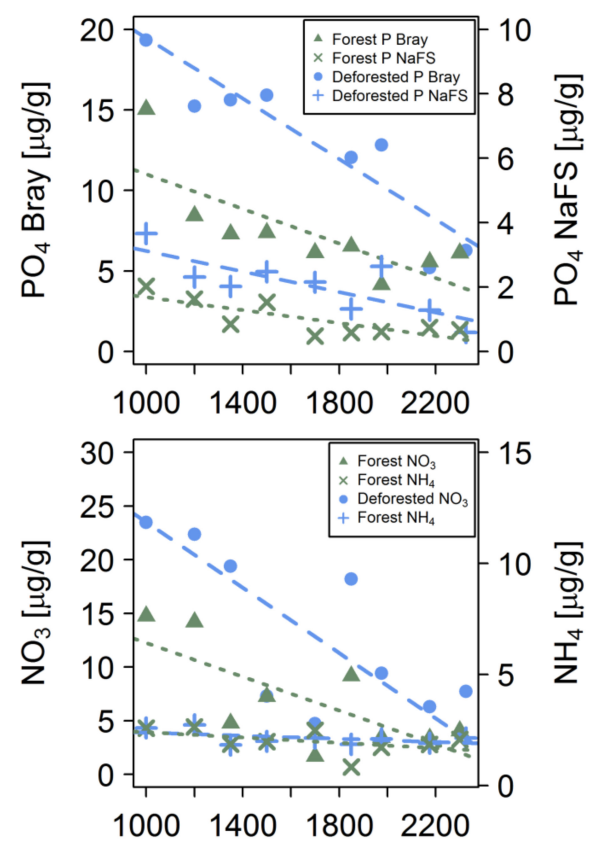

Figure 2. Linear regression showing changes in plant available nutrients with distance from the town of Mangily in meters. (a) Negative correlation between distance and extractable orthophosphate as measured by two different methods (Bray-1 and NaFS) in forested (Bray-1 y $=-0.0053 \mathrm{x}+16.25 R^{2}=0.58$, NaFS $\left.\mathrm{y}=-0.001 \mathrm{x}+2.65 R^{2}=0.62(\mathrm{p}<0.05)\right)$ and deforested areas (Bray-1 $\mathrm{y}=-0.0094 \mathrm{x}+28.84, R^{2}=0.82, \mathrm{NaFS}$ $\left.\mathrm{y}=-0.0016 \mathrm{x}+4.71 R^{2}=0.63(p<0.05)\right) .(\mathbf{b})$ Extractable $\mathrm{N}$ in forested $\left(\mathrm{NO}_{3}{ }^{-} \mathrm{y}=-0.0078 \mathrm{x}+19.97 R^{2}=0.53\right.$ $\left.(p<0.05), \mathrm{NH}_{4}{ }^{+} \mathrm{y}=-0.0006 \mathrm{x}+2.99 R^{2}=0.23(p>0.05)\right)$ and deforested areas $\left(\mathrm{NO}_{3}{ }^{-} \mathrm{y}=-0.0123 \mathrm{x}+33.738\right.$ $\left.R^{2}=0.54(p<0.05), \mathrm{NH}_{4}{ }^{+} \mathrm{y}=-0.0004 \mathrm{x}+2.81 R^{2}=0.31(p>0.05)\right)$. 


\subsection{Fatty Acid Analysis}

D. madagascariensis root NLFA $16: 1 \omega 5$ values analysed with a t-test proved to be significantly higher in forest roots than roots from deforested areas $(t=-3.21, \mathrm{df}=7, \mathrm{p} \leq 0.01)$. Overall D. madagascariesis NLFA values ranged from $4.5 \mathrm{nmol} / \mathrm{g}$ in a sample from deforested areas to $127 \mathrm{nmol} / \mathrm{g}$ in a sample from forest roots (Figure 3).

Root PLFA 16:1 $\omega 5$ was only detectable in four of the samples, three of which belonged to forest area roots with the highest value of $7.64 \mathrm{nmol} / \mathrm{g}$. Soil NLFA 16:1 $\omega 5$ was significantly higher in the forest areas $(\mathrm{t}=-2.25, \mathrm{df}=8, p \leq 0.05)$. A similar tendency was found for soil PLFA 16:1 $\omega 5$, but the difference was not significant $(\mathrm{t}=-1.05, \mathrm{df}=7, p$-value $=0.33$ ) (Figure 3 ).
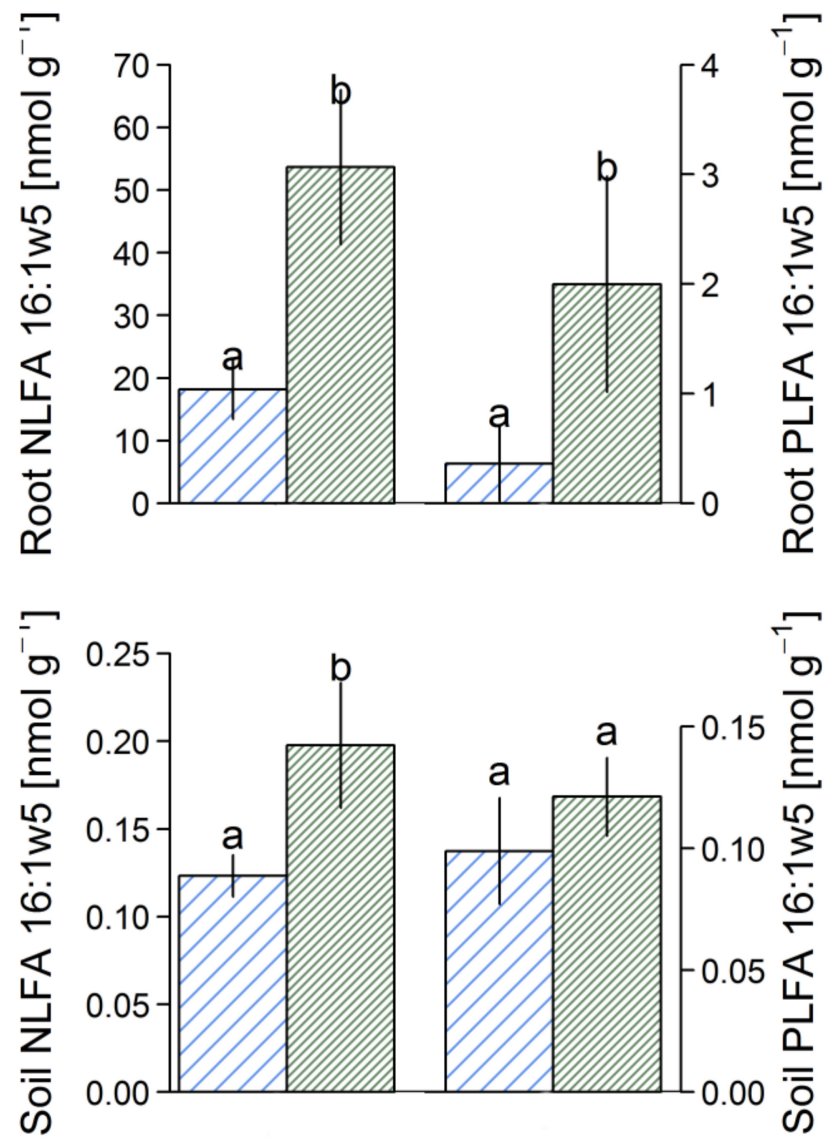

Figure 3. Effect of deforestation on arbuscular mycorrhizal (AM) fungi variables of Didierea madagascariensis in deforested (D) and forested (F) areas, fatty acid 16:1 $\omega 5$ content in roots of D. madagascariensis (nmol/g dried root) in forested and deforested areas (upper panel), and fatty acid 16:1 $\omega 5$ in soil (nmol/g dry soil) collected in forested and deforested areas (lower panel). Error bars indicate $95 \%$ confidence interval and different letters above the bars indicate a significant difference (paired $t$-test, $\mathrm{n}=9, p<0.05$ ).

\subsection{Microscopic Analysis of Root Colonization}

Total colonization levels (Figure 4) were significantly higher in D. madagascariensis roots from the forest than in roots from burned areas $(\mathrm{t}=-5.87, \mathrm{df}=8, p \leq 0.001)$, and the same was found for vesicle colonization $(t=5.07, \mathrm{df}=8, p \leq 0.001)$ and arbuscules $(\mathrm{t}=-5.02, \mathrm{df}=8, p \leq 0.001)$. Hyphal colonization was analysed with a Mann-Whitney U test, which showed hyphal colonization to be significantly higher in forest roots (chi-squared $=3.95, \mathrm{df}=1, p \leq 0.05$ ) 


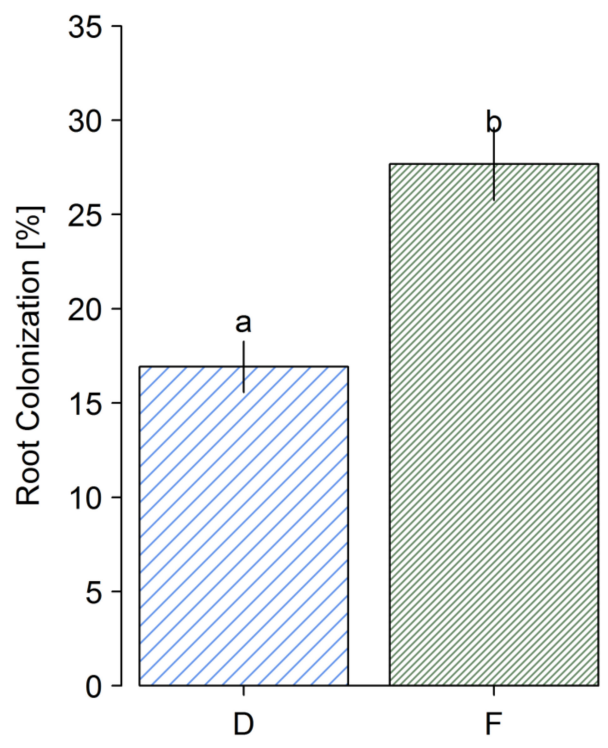

Figure 4. Effect of deforestation on AM fungi root colonization levels (\%) in D. madagascariensis in deforested (D) and forested (F) areas. Error bars indicate 95\% confidence interval and different letters above the bars indicate a significant difference (paired $t$-test, $\mathrm{n}=9, p<0.05$ ).

\subsection{Soil Spore Density}

Total spore density tended to be higher in forest soil than in burned deforested soil (Figure 5), but spore densities varied greatly, from 1600 to 4600 spores per $100 \mathrm{~g}$ of soil $(\mathrm{t}=-0.64$, $\mathrm{df}=8$, $p$-value $=0.54)$. The density of the bigger spores (Class A) showed a very weak tendency to be higher in forest soils $(\mathrm{t}=-1.16, \mathrm{df}=8, p$-value $=0.28)$. The density of the medium-sized spores (Class $\mathrm{B})$ showed no significant differences between areas when analysed with the Mann-Whitney $U$ test ( $p$-value $=0.93)$. The density of the smallest spores (Class $C$ ) showed no significant differences between areas $(\mathrm{t}=-0.61, \mathrm{df}=8, p$-value $=0.56)$.

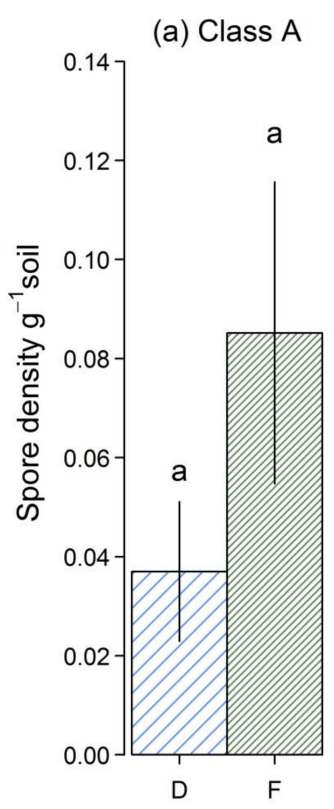

(b) Class B

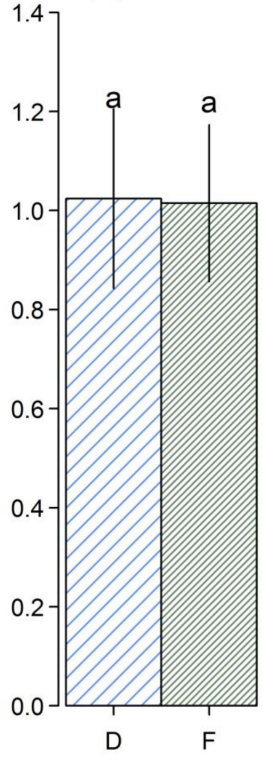

(c) Class C

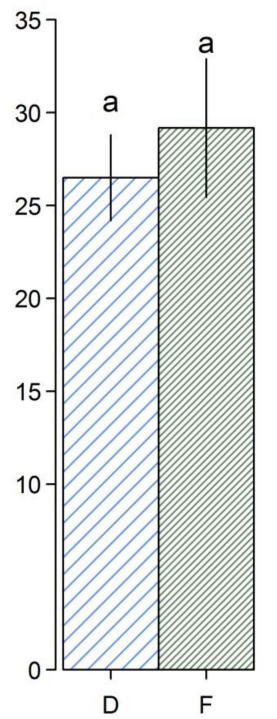

(d) Class T

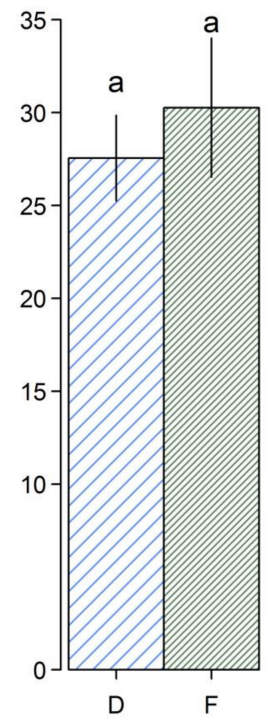

Figure 5. Spore densities in $100 \mathrm{~g}$ of dry soil in deforested area (D) and forested area (F): (a) total spores, (b) Class A spores (c), Class B spores (d), and Class C spores. Error bars indicate $95 \%$ confidence interval. In all cases, differences were nonsignificant according to a paired $t$-test. 


\subsection{Relationships between AM Fungi Abundance and Soil Parameters}

Correlation analysis of soil chemical properties (Appendix A) showed that soil $\mathrm{pH}$ was positively correlated with $\mathrm{NO}_{3}{ }^{-}$, extractable phosphate, total $\mathrm{N}$, and soil carbon. Extractable phosphate and $\mathrm{NO}_{3}{ }^{-}$were strongly correlated with each other. Soil ammonium was not linearly correlated with any other soil parameter. Colonization levels were significantly negatively correlated with soil total $\mathrm{N}$, total $\mathrm{C}$, and $\mathrm{pH}$. Root PLFA 16:1 $\omega 5$ increased significantly with distance from the town and was negatively correlated with $\mathrm{NO}_{3}$ and $\mathrm{pH}$. Soil PLFA 16:1 $\omega 5$ increased with total soil C. Soil NLFA 16:1 $\omega 5$ was positively correlated with soil PLFA 16:1 $\omega 5$. Spore density was not significantly correlated with any of the measured soil parameters, though correlation with soil NLFA was near significance ( $p$ $=0.08$ ).

\section{Discussion}

In the present study, we report for the first time the effect of slash-and-burn practices that have increased soil available nutrients and decreased AM fungal abundance in the soil of the dry Spiny Forest on red sand in southwestern Madagascar. Deforestation and the use of fire to clear land can have drastic effects on forest ecosystem functioning and compromise the continuity of many important ecosystem services, especially in tropical countries (Bradshaw, 2008 [45]; Beliveau, 2015 [10]; Gay-des-Combes 2017 [19]). Our results are an original contribution to understanding the effect of slash-and-burn on AM communities, since previous studies have shown contrasting results when reporting changes in soil chemistry and soil mycorrhizal communities, reporting systems with different levels of resilience to slash-and-burn disturbance (Kauffman 1992 [46], Certini 2005 [47], Cairney and Bastias 2007 [48]; García de León 2018 [16]). As a pivotal part of the soil microbial community, the reduced AM fungi abundance observed in our study may have consequences extending throughout the rest of the soil microbial and plant communities (Rillig, 2004 [49]). All of these alterations are important to know as they may affect the possibility and direction of secondary succession, ecosystem regeneration, or the potential for sustainable agricultural or forestry use of the affected land in this highly understudied landscape (Waeber 2015 [50]).

\subsection{Soil Chemistry}

Results show a marked increase of soil $\mathrm{pH}$ in areas affected by deforestation, accompanied by an increase in total carbon and nitrogen, orthophosphate, and nitrate. In contrast, deforestation did not significantly affect levels of soil ammonium. Overall soil chemistry characteristics position the Spiny Forest soil as a poor mineral soil with low carbon and nutrient contents, similar to reference values for arid sandy entisols (Brady 2002 [51]). Our regression analysis also showed that the distance from the town significantly affected nutrient values. Transects located closest to the town showed the highest levels of $\mathrm{pH}$ and soil nutrients within each area (both forested and deforested), while those furthest had similarly low values. Thus, we conclude that distance from the town is related to the degree of disturbance caused by man, with areas closest to the town having been more exhaustively cleared and exploited. It is worth remarking that correlations between soil chemical parameters and distance from town in all cases seemed to be higher in deforested than in forest areas. This may be due to the fact that, though people unlawfully enter the forest reserve, disturbance levels were much higher in deforested areas and thus had greater effects. Additionally, though deforested land is progressively cleared, this may not be the form taken by the anthropogenic disturbance in the forest. It was observed that people tend to enter the forest laterally at many different points along the road that runs parallel to the reserve border and, thus, this could partially explain why the correlation of soil nutrients and $\mathrm{pH}$ levels with distance from town was less strong in the forest.

Our soil chemistry results fit well into the established knowledge that slashing and burning plant biomass causes a release of nutrients (Giardina 2000a [9]), which then usually undergo leaching from soil if they are not promptly immobilized by vegetation or microorganisms (Gay-des-Combes 
2017 [19]). In this ecosystem, however, rainfall is very low and the sampling was performed at the end of the long dry season. These conditions, together with the lack of nutrient uptake by plants (as cleared land is not yet cultivated) may have caused reduced nutrient leaching observed in the results. Observed $\mathrm{pH}$ increases constitute a common finding, as vegetation loss alone can cause base cation release that increases soil pH (Brady 2002 [51]). Additionally, fire alone increases soil pH because of organic acid denaturation and the release of base cations (Certini 2005 [47]). Additionally, ash also contains base cations and has an alkalizing effect on soils (Kauffman 1993 [52]).

The high levels of total nitrogen and carbon in deforested areas may appear to be a surprising result, as one might expect higher levels of nitrogen and carbon in forest areas due to the higher biomass. However, a recent meta-analysis (Wang 2012 [53]) shows that fire causes increases in total $\mathrm{C}$ and $\mathrm{N}$ in forest mineral soil. Incorporation of ashes and burned or unburned residues from the vegetation can cause $\mathrm{C}$ and $\mathrm{N}$ increases in an otherwise poor mineral soil (De Marco 2005 [54]). In the studied area, the clearing of land is often selective; locals partially cut and burn wood which is useful, leaving some organic matter to lie on the land to burn later. Thus, this may have significantly increased the organic matter in the poor sandy soil. Also, in such a warm and tropical climate, degradation of the litter, mineralization, and plant uptake of nutrients is thought to be fast (Garcia-Méndez 1991 [55]) and it may be that most nitrogen and carbon is stored in plant biomass and little in the soil. On the other hand, fire is also known to cause increases in soil total $C$ due to the formation of more recalcitrant forms that are not easily degraded (Schmidt 2000 [56]). Such black carbon can constitute over $35 \%-40 \%$ of the total carbon in burned soils (Certini 2005 [47]). In our study, samples from deforested areas had obvious signs of containing carbon and were darker than soil from the forest, indicating black carbon (Ketterings 2000 [57]). Higher levels of nitrate in deforested areas may be firstly explained by the increase in total $\mathrm{N}$ available for mineralization. Secondly, the proportion of mineral $\mathrm{N}$ was higher in deforested than in forested areas, which may point towards an increased mineralization rate. Fire and slash-and-burn practices are known to cause pulses in $\mathrm{NH}_{4}{ }^{+}$through pyromineralization of organic $\mathrm{N}$, which is later converted to $\mathrm{NO}_{3}{ }^{-}$(Ellingson 2000 [58]). Slash-and-burn may also cause indirect increases in mineralization due to $\mathrm{pH}$ elevation and the greater availability of base cations and nutrients such as $\mathrm{Ca}$ and $\mathrm{Mg}$. Interestingly, soil $\mathrm{NH}_{4}{ }^{+}$showed no significant differences between cleared and forested land. It may be the case that increased soil $\mathrm{pH}$ caused nitrification in deforested areas to decrease the soil $\mathrm{NH}_{4} / \mathrm{NO}_{3}$ ratio. However, such differences could also be explained by $\mathrm{NH}_{4}{ }^{+}$ volatilization during fire or differential plant uptake of mineral $\mathrm{N}$ forms, and thus, in order to assert possible differences in mineralization rates, incubation experiments should be conducted.

The marked increase in available phosphate is also a known effect of deforestation and fire, as organic soil $\mathrm{P}$ is converted to orthophosphate through pyromineralization and higher $\mathrm{pH}$ increases $\mathrm{P}$ availability in the absence of Ca (Giardina 2000a [9]). Other studies have also shown that increases in extractable phosphate are a sensitive indicator of the use of fire in slash-and-burn practices (Giardina 2000b [59]), and the clear correlation between the distance from Mangily and the P levels reinforces this.

\subsection{AMF Abundance in Soil and Roots of D. Madagascariensis}

Total AM fungi abundance in the Spiny Forest, as measured by neutral lipid and phospholipid fatty acids, was overall quite low in both forested and deforested areas. Fatty acid values were similar to those reported for other arid sandy soils (Hammer et al., 2011 [60]). Though AM fungi abundance measured with NLFA and PLFA 16:1 $\omega 5$ tended to be negatively affected by deforestation, this trend was only marginally significant in NLFA 16:1 $\omega 5$. As NLFA may be used as a proxy for AM fungal abundance in soil (Olsson 1995 [61]), we may conclude that deforestation caused a reduction of the hyphal network. Other studies indicate that the direct response of mycorrhizal fungus biomass to deforestation and use of fire is not clear (Cairney \& Bastias 2007 [48]). As in the present study, other studies found a decrease in fungal mycelium after prescribed fires (D'Ascoli 2005 [62], Rutigliano, 2007 [63]). The reasons for such decreases are thought to be soil sterilization, physical disruption of the hyphal network, and removal of potential hosts from soil. However, it is believed that effects 
vary greatly depending on the time elapsed since the disturbance. Though fungi are thought to be more sensitive to fire than bacterial groups (D'Ascoli 2005 [62], Ginzburg 2012 [64]), it may be that the fertilization effect often witnessed after deforestation, together with the greater ability of fungi to utilize recalcitrant materials (Leckie 2004 [65]), allows fungal biomass to recover after fires.

No effects of deforestation practice on soil spore densities were seen in this study. This appears to be a common finding (Johnson 1997 [28], Muchane 2012 [29], Zhang 2004 [66]), although other studies have also found either higher or lower spore densities in disturbed areas (Sene 2012 [67], Korb et al., 2000 [68]). In any event, it seems that spore densities may not be a good measure for the response of active mycorrhizal biomass-firstly, because we cannot estimate the age of spores in this study, and secondly, because sporulation depends on many factors and is often species specific (Rosendahl 2008 [69]).

Overall, the predominant effects of deforestation on the AM fungal community in soil are likely to be indirect. Thus, in a longer perspective, plant succession following disturbance is the most important factor that explains the direction of AM fungal abundance and community composition changes. As our study was conducted at an initial stage of secondary succession, before significant colonization of new vegetation, further studies would be needed to establish the direction of said succession and AM status of colonizing plants.

D. madagascariensis seedlings showed overall root colonization levels that varied from $12.9 \%$ to $33.4 \%$, and this constitutes the first time the AM symbiosis has been described in the Didiereaceae family. Colonization structures and AM fungus fatty acid markers significantly decreased in seedling roots harvested in deforested areas. It may be that disruption of the AM fungal hyphal network, rather than changes in inoculum potential (spore densities), negatively affected the AM symbiosis in D. madagascarinsis seedlings, as suggested by Pattinson et al. (1999 [70]). However, other studies show that the response of AM root colonization to deforestation and fire appears to be plant-species specific, i.e., root colonization is known to both increase and decrease depending on the plant species and AM type, independently of changes in AM fungi abundance in soil. Azul and collaborators (2010 [71]) reported decreases in root AM fungi colonization levels of Festuca species that successfully occupied areas after fires. These results are in accordance with ours, as D. madagascariensis seedlings appeared to be one of few species that were able to colonize the cleared land.

In our study, negative correlations found between root colonization and increased nutrient availability (especially nitrogen) and $\mathrm{pH}$ may partly explain the changes in AM symbiosis in D. madagascariensis. According to the trade balance model, the increased nutrient availability in cleared land may have made investment in an AM fungal partner less advantageous than plant-allocated carbon above ground (Johnson 2010 [25]). Higher $\mathrm{pH}$ is also known to reduce colonization levels as nutrients like $\mathrm{P}$ become available. In the same way, decreased nutrient availability and increased competition in the forest may have made investment in a mycorrhizal symbiont more worthwhile. However, more experimental work would be required to disentangle which are the predominant factors affecting D. madagascariensis AM symbiosis (disturbance, reduced inoculum potential, or nitrogen, phosphorus, and carbon exchange budgets), with controlled pot experiments evaluating the importance of each factor. Further field research is also needed to assess AM symbiosis in other Spiny Forest species, both in the forest and the grasses that colonize cleared land.

Both in the case of soil chemistry and AM fungal abundance, one must keep in mind the limitations of such a field study. Both controlled experiments and vegetation studies incorporating temporal aspects are needed in order to make further assumptions on the mechanisms and dynamics behind the presented results. Lastly, due to the nature of the slash-and-burn practices employed (slow advancement of a deforestation front, selective clearing, and burning), the areas closest to the town suffer from higher levels of fire disturbance, but it is probable that also the longest time has elapsed since the first fire disturbance event began. As time passed since slash-and-burn events seems to be a factor of major importance in determining the response of soil and microbial communities, sampling at different stages of the system's change may dim the clearness of response patterns and this should be addressed in experimental studies. However, the paired design implemented in this 
field study allowed us to determine that, overall, the differences between forest and burned areas are consistent and distinct.

\section{Conclusions}

This study constitutes a robust preliminary investigation of the effects of slash-and-burn practices on soil chemistry and AM fungi abundance in the Spiny Forest ecosystem of southwestern Madagascar. Results show clear effects of burning practices used by the inhabitants, where slash-and-burn caused a surge in plant available nutrients and a decline in AM fungi in soil and in D. madagascariensis roots. This is the first study to report such an event in southwestern ecosystems in Madagascar. Further studies are needed to assess the total loss of nutrients the ecosystem suffers through volatilization of the forest above and below ground biomass and to discern the response dynamics of nutrient stocks and AM fungi to seasonality and vegetation cover changes after burning at longer time scales. Given the high originality of this endangered ecosystem and the importance of AM fungi in vegetation succession, such knowledge is essential in order to understand and predict the future direction of vegetation patterns and ecosystem resilience to human fire practices.

Author Contributions: Conceptualization, A.D.B. and P.A.O.; Methodology, A.D.B. and P.A.O.; Formal Analysis, A.D.B. and P.A.O.; Writing-Original Draft Preparation, A.D.B.; Writing-Review \& Editing, A.D.B. and P.A.O.; Supervision, P.A.O.

Funding: Alicia M. Donnellan was funded by a Swedish-Spanish Foundation SAU Scholarship.

Acknowledgments: The authors would like to thank Edith Hammer, Johannes Rousk, and Stefan Andersson for their thoughts on the manuscript. Warm thanks to Fundación Yelcho and NGO Bel Avenir for having made the project in Madagascar possible and to Alicia Bonilla Alcácer for her assistane in the field. Thank you to Maj-Lis Gernersson for her help with soil chemistry analysis.

Conflicts of Interest: The authors declare no conflict of interest.

\section{Appendix A.}

Table A1. Spearman's rank correlation coefficients between soil properties (a), between AM fungal abundance and soil properties (b) and between AM fungal abundance (c) with significance tests $\left({ }^{*} p \leq 0.05\right.$. $\left.{ }^{* *} p \leq 0.01\right)$.

(a)

\begin{tabular}{|c|c|c|c|c|c|c|c|c|c|}
\hline & $\begin{array}{l}\text { Distance } \\
\text { (m) }\end{array}$ & $\begin{array}{l}\text { NH4 } \\
(\mu \mathrm{g} / \mathrm{g})\end{array}$ & $\begin{array}{l}\text { NO3 } \\
(\mu \mathrm{g} / \mathrm{g})\end{array}$ & $\begin{array}{l}\mathrm{N} \\
(\mu \mathrm{g} / \mathrm{g})\end{array}$ & $\begin{array}{l}\text { Bray } \\
(\mu \mathrm{g} / \mathrm{g})\end{array}$ & $\begin{array}{l}\mathrm{NaFS} \\
(\mu \mathrm{g} / \mathrm{g})\end{array}$ & $\begin{array}{l}\mathrm{C} \\
(\mathrm{mg} / \mathrm{g})\end{array}$ & $\begin{array}{l}\text { C/N } \\
\text { Ratio }\end{array}$ & $\mathrm{pH}$ \\
\hline Distance & 1 & -0.45 & $-0.57^{* *}$ & -0.12 & $-0.68^{* *}$ & $-0.58^{* *}$ & -0.22 & -0.28 & $-0.49 *$ \\
\hline $\mathrm{NH} 4$ & & 1 & 0.31 & 0.09 & 0.4 & 0.46 & 0.2 & 0.24 & 0.13 \\
\hline NO3 & & & 1 & 0.64 ** & $0.75^{* *}$ & 0.62 ** & $0.74 * *$ & 0.55 * & $0.79 * *$ \\
\hline $\mathrm{N}$ & & & & 1 & 0.41 & 0.29 & $0.96^{* *}$ & 0.43 & $0.74^{* *}$ \\
\hline Bray & & & & & 1 & $0.86^{* *}$ & $0.47^{*}$ & 0.37 & $0.81 * *$ \\
\hline NaFS & & & & & & 1 & 0.35 & 0.36 & $0.60^{* *}$ \\
\hline C & & & & & & & 1 & $0.61^{* *}$ & $0.73 * *$ \\
\hline Ratio & & & & & & & & 1 & 0.31 \\
\hline $\mathrm{pH}$ & & & & & & & & & 1 \\
\hline
\end{tabular}

\begin{tabular}{|c|c|c|c|c|c|c|c|c|c|}
\hline \multicolumn{10}{|c|}{ (b) } \\
\hline & $\begin{array}{l}\text { Distance } \\
\text { (m) }\end{array}$ & $\begin{array}{l}\text { NH4 } \\
(\mu \mathrm{g} / \mathrm{g})\end{array}$ & $\begin{array}{l}\text { NO3 } \\
(\mu \mathrm{g} / \mathrm{g})\end{array}$ & $\begin{array}{l}N \\
(\mu \mathrm{g} / \mathrm{g})\end{array}$ & $\begin{array}{l}\text { Bray } \\
(\mu \mathrm{g} / \mathrm{g})\end{array}$ & $\begin{array}{l}\text { NaFS } \\
(\mu \mathrm{g} / \mathrm{g})\end{array}$ & $\begin{array}{l}\mathrm{C} \\
(\mathrm{mg} / \mathrm{g})\end{array}$ & Ratio & $\mathrm{pH}$ \\
\hline Colonization & 0.3 & 0.14 & -0.34 & $-0.5^{*}$ & -0.37 & -0.34 & -0.45 * & -0.22 & $-0.5^{*}$ \\
\hline Root PLFA 16:1 $\omega 5$ & $0.46^{*}$ & -0.28 & $-0.46^{*}$ & -0.15 & -0.4 & -0.17 & -0.18 & -0.09 & $-0.46^{*}$ \\
\hline Root NLFA $16: 1 \omega 5$ & 0.03 & -0.15 & -0.31 & -0.23 & -0.26 & -0.23 & -0.21 & -0.02 & -0.33 \\
\hline Soil NLFA $16: 1 \omega 5$ & -0.16 & 0.08 & 0.11 & 0.33 & -0.06 & -0.11 & 0.42 & 0.24 & 0.13 \\
\hline Soil PLFA 16:1 $\omega 5$ & -0.21 & 0.36 & 0.19 & 0.36 & 0.14 & 0.13 & $0.47^{*}$ & 0.34 & 0.26 \\
\hline Spores & -0.1 & 0.16 & 0.15 & -0.08 & 0.06 & 0.13 & 0.08 & 0.28 & -0.04 \\
\hline
\end{tabular}


Table A1. Cont.

(c)

\begin{tabular}{lllllll}
\hline & $\begin{array}{l}\text { Colonization } \\
(\mathbf{\%})\end{array}$ & $\begin{array}{l}\text { RootPLFA } \\
(\mathbf{n m o l} \text { g soil }\end{array}$
\end{tabular}

\section{References}

1. Harper, G.J.; Steininger, M.K.; Tucker, C.J.; Juhn, D.; Hawkins, F. Fifty years of deforestation and forest fragmentation in Madagascar. Environ. Conserv. 2007, 34, 325-333. [CrossRef]

2. Goodman, S.M.; Benstead, J.P. The Natural History of Madagascar; Chicago Press: Chicago, IL, USA, 2003.

3. Seddon, N.; Tobias, J.; Yount, J.W.; Ramanampamonjy, J.R.; Butchart, S.; Randrianizahana, H. Conservation issues and priorities in the Mikea Forest of south-western Madagascar. Oryx 2000, 34, 287-304. [CrossRef]

4. Callmander, M.W.; Phillipson, P.B.; Schatz, G.E.; Andriambololonera, S.; Rabarimanarivo, M.; Rakotonirina, N.; Raharimampionona, J.; Chatelain, C.; Gautier, L.; Lowry, P. The endemic and non-endemic vascular flora of Madagascar updated. Plant Ecol. Evol. 2011, 144, 121-125. [CrossRef]

5. Wilmé, L.; Goodman, S.M.; Ganzhorn, J.U. Biogeographic Evolution of Madagascar's Microendemic Biota. Science 2006, 312, 1063-1065. [CrossRef] [PubMed]

6. Raherison, S.M.; Grouzis, M. Plant biomass, nutrient concentration and nutrient storage in a tropical dry forest in south-west Madagascar. Plant Ecol. 2005, 180, 33-45. [CrossRef]

7. Casse, T.; Milhoj, A.; Ranaivoson, S.; Randriamanarivo, J.R. Causes of deforestation in southwestern Madagascar: What do we know? Forest Policy Econ. 2004, 6, 33-48. [CrossRef]

8. Randriambanona, H.; Razanaka, S.; Randriamalala, J.; Grouzis, M. Secondary succession and root biomass changes in Madagascar dry deciduous forest (Mikea Forest). Rev. Ecol.-Terre Vie 2018, 73, 283-292.

9. Giardina, C.P.; Sanford, R.L.; Dockersmith, I.C.; Jaramillo, V.J. The effects of slash burning on ecosystem nutrients during the land preparation phase of shifting cultivation. Plant Soil 2000, 220, 247-260. [CrossRef]

10. Beliveau, A.; Davidson, R.; Lucotte, M.; Lopes, L.O.D.; Paquet, S.; Vasseur, C. Early effects of slash-and-burn cultivation on soil physicochemical properties of small-scale farms in the Tapajos region, Brazilian Amazon. J. Agric. Sci. 2015, 153, 205-221. [CrossRef]

11. Ribeiro Filho, A.; Adams, C.; Manfredini, S.; Aguilar, R.; Neves, W.A. Dynamics of soil chemical properties in shifting cultivation systems in the tropics: A meta-analysis. Soil Use Manag. 2015, 31, 474-482. [CrossRef]

12. Don, A.; Schumacher, J.; Freibaurer, A. Impact of tropical land-use change on soil organic carbon stocks-A meta-analysis. Glob. Change Biol. 2011, 17, 1658-1670. [CrossRef]

13. Mukul, S.A.; Herbohn, J. The impacts of shifting cultivation on secondary forests dynamics in tropics: A synthesis of the key findings and spatio temporal distribution of research. Environ. Sci. Policy 2016, 55, 167-177. [CrossRef]

14. Bellgard, S.E.; Whelan, R.J.; Muston, R.M. The impact of wildfire on vesicular arbuscular mycorrhizal fungi and their potential to influence the re-establishment of post-fire plant communities. Mycorrhiza 1994, 4, 139-146. [CrossRef]

15. Rodrigues, J.L.M.; Pellizari, V.; Mueller, R.; Baek, K.; Jesuse, E.C.; Paula, F.; Mirzaa, B.; Hamaoui, G.; Mui Tsai, S.; Feiglf, B.; et al. Conversion of the Amazon rainforest to agriculture results in biotic homogenization of soil bacterial communities. Proc. Natl. Acad. Sci. USA 2012. [CrossRef] [PubMed]

16. García de León, D.; Neuenkamp, L.; Moora, M.; Öpik, M.; Davison, J.; Peña-Venegas, C.P.; Zobel, M. Arbuscular mycorrhizal fungal communities in tropical rain forest are resilient to slash-and-burn agriculture. J. Trop. Ecol. 2018, 34, 186-199. [CrossRef]

17. Styger, E. Degrading uplands in the rainforest region of Madagascar: Fallow biomass, nutrient stocks, and soil nutrient availability. Agroforest. Syst. 2009, 77, 107-122. [CrossRef]

18. Leprun, J.C.; Grouzis, M.; Randriambanona, H. Post-cropping change and dynamics in soil and vegetation properties after forest clearing: Example of the semi-arid Mikea Region (south-western Madagascar). Geoscience 2009, 341, 526-537. [CrossRef] 
19. Gay-des-Combes, J.M.; Robroek, B.J.M.; Herve, D.; Guillaume, T.; Pistocchi, C.; Mills, R.T.E.; Buttler, A. Slash-and-burn agriculture and tropical cyclone activity in Madagascar: Implication for soil fertility dynamics and corn performance. Agric. Ecosyst. Environ. 2017, 239, 207-218. [CrossRef]

20. Runyan, C.W.; D'Odorico, P.; Lawrence, D. Physical and biological feedbacks of deforestation. Rev. Geophys. 2012, 50, RG4006. [CrossRef]

21. Styger, E.; Rakotondramasy, H.; Pfeffer, M.J.; Fernandes, E.C.M.; Bates, D.M. Influence of slash-and-burn farming practices on fallow succession and land degradation in the rainforest region of Madagascar. Agr. Ecosyst. Environ. 2007, 119, 257-269. [CrossRef]

22. Raharimalala, O.; Buttler, A.; Schlaepfer, R.; Gobat, J.M. Quantifying biomass of secondary forest after slash and burn cultivation in central Menabe, Madagascar. J. Trop. For. Sci. 2012, 24, 474-489.

23. Newman, E.I.; Reddell, P. The distribution of mycorrhizas among families of vascular plants. New Phytol. 1987, 16, 744-751. [CrossRef]

24. Smith, S.E.; Read, D.J. Mycorrhizal Symbiosis, 3rd ed.; Academic Press: London, UK, 2008.

25. Johnson, N.C. Resource stoichiometry elucidates the structure and function of arbuscular mycorrhizas across scales. New Phytol. 2010, 185, 631-647. [CrossRef] [PubMed]

26. Van der Heijden, M.G.A.; Boller, T.; Wiemken, A.; Sanders, I.R. Different arbuscular mycorrhizal fungal species are potential determinants of plant community structure. Ecology 1998, 79, 2081-2091. [CrossRef]

27. Rillig, M.C. Large contribution of arbuscular mycorrhizal fungi to soil carbon pools in tropical forest soils. Plant Soil 2001, 223, 167-177. [CrossRef]

28. Johnson, N.C.; Wedin, D.A. Soil, carbon, nutrients and mycorrhizae during conversion of dry tropical forest to grassland. Ecol. Appl. 1997, 7, 171-182. [CrossRef]

29. Muchane, M.N.; Muchane, M.; Mugoya, C.; Masiga, C.W. Effect of land use system on Arbuscular mycorrhiza fungi in Maasai Mara ecosystem, Kenya. Afr. J. Microbiol. Res. 2012, 6, 3904-3916.

30. Wubet, T.; Kottke, I.; Teketay, D.; Oberwinkler, F. Mycorrhizal status of indigenous trees in dry Afromontane forests of Ethiopia. For. Ecol. Manag. 2003, 179, 387-399. [CrossRef]

31. Tedersoo, L.; Bahram, M.; Jairus, T.; Bechem, E.; Chinoya, S.; Mpumba, R.; Leal, M.; Randrianjohany, E.; Razafimandimbison, S.; Sadam, A.; et al. Spatial structure and the effects of host and soil environments on communities of ectomycorrhizal fungi in wooded savannas and rain forests of Continental Africa and Madagascar. Mol. Ecol. 2011, 20, 3071-3080. [CrossRef] [PubMed]

32. Ducousso, M.; Ramanankierana, H.; Duponnois, R.; Rabévohitra, R.; Randrihasipara, L.; Vincelette, M.; Dreyfus, B.; Prin, Y. Mycorrhizal status of native trees and shrubs from eastern Madagascar litoral Forests with special emphasis on one new ectomycorrhizal endemic family, the Asteropeiaceae. New Phytol. 2008, 178, 233-238. [CrossRef] [PubMed]

33. Yokoya, K.; Zettler, L.W.; Kendon, J.P.; Bidartondo, M.I.; Stice, A.L.; Skarha, S.; Sarasan, V. Preliminary findings on identification of mycorrhizal fungi from diverse orchids in the Central Highlands of Madagascar. Mycorrhiza 2015, 25, 611-625. [CrossRef] [PubMed]

34. Ramanankierana, H. Personal Communication; Laboratoire de Microbiologie de l'Environnement: Antananarivo, Madagascar, 2018.

35. Olsson, P.A. Signature fatty acids provide tools for determination of the distribution and interactions of mycorrhizal funghi in soil. FEMS Microbiol. Ecol. 1999, 29, 303-313. [CrossRef]

36. Salomon, J.N. Le Sud-ouest de Madagascar, Etude de Geographie Physique; Presses Universitaires Bordeaux: Bordeaux, France, 1987; p. 998.

37. Cabanis, Y.; Chabouis, L.; Chabouis, J. Végétaux et Groupements Végétaux de Madagascar et des Mascareignes; Bureau Pour le Développement de la Production Agricole: Antananarivo, Madagascar, 1987; pp. 1969-1970.

38. Bray, R.H.; Kurtz, L.T. Determination of Total Organic and Available Forms of Phosphorus in Soils. Soil Sci. 1945, 59, 39-45. [CrossRef]

39. Van Aarle, I.M.; Olsson, P.A. Fungal lipid accumulation and development of mycelial structures by two arbuscular mycorrhizal fungi. Appl. Environ. Microbiol. 2003, 69, 6762-6767. [CrossRef] [PubMed]

40. Blight, E.G.; Dyer, W.J. A rapid method of total lipid extraction and purification. Can. J. Biochem. Physiol. 1959, 37, 911-917. [CrossRef]

41. Phillips, J.M.; Hayman, D.S. Improved procedures for clearing roots and staining parasitic and vesicular-arbuscular mycorrhizal fungi for rapid assesssment of infection. Trans. Br. Mycol. Soc. 1970, 55, 158-161. [CrossRef] 
42. McGonigle, T.P.; Miller, M.H.; Evans, D.G.; Fairchild, G.L.; Swan, J.A.A. New Method which gives an Objective Measure of Colonization of Roots by Vesicular-Arbuscular Mycorrhizal Fungi. New Phytol. 1990, 115, 495-501. [CrossRef]

43. Mckenney, M. Improved Method for Quantifying Endomycorrhizal Fungi Spores from Soil. Mycologia 1987, 79, 779-782. [CrossRef]

44. R Core Team. R: A Language and Environment for Statistical Computing; R Foundation for Statistical Computing: Vienna, Austria, 2017; Available online: https:/ / www.R-project.org/ (accessed on 27 August 2018).

45. Bradshaw, C.J.A.; Sodhi, N.S.; Brook, B.W. Tropical turmoil: A biodiversity tragedy in progress. Front. Ecol. Environ. 2008, 2, 79-87. [CrossRef]

46. Kauffman, J.B.; Till, H.M.; Shea, R.W. Biochemistry of deforestation and biomass burning. ACS Symp. Ser. 1992, 483, 428-4556.

47. Certini, G. Effects of fire on properties of forest soils: A review. Oecologia 2005, 143, 1-10. [CrossRef] [PubMed]

48. Cairney, J.W.G.; Bastias, B.A. Influences of fire on forest soil fungal communities. Can. J. For. Res. 2007, 37, $207-215$. [CrossRef]

49. Rillig, M.C. Arbuscular mycorrhizas and terrestial ecosystem processes. Ecol. Lett. 2004, 7, 740-754. [CrossRef]

50. Waeber, P.O.; Wilme, L.; Ramamonjisoa, B.; Garcia, C.; Rakotomalala, D.; Rabemananjara, Z.H.; Sorg, J.P. Dry forests in Madagascar: Neglected and under pressure. Int. For. Rev. 2015, 17, 127-148. [CrossRef]

51. Brady, N.C.; Weil, R.R. Nature and Properties of Soils; Prentice Hall-Science: Upper Saddle River, NJ, USA, 2002; p. 960.

52. Kauffman, J. Biomass and Nutrient Dynamics Associated with Slash Fires in Neotropical Dry Forests. Ecology 1993, 74, 140-151. [CrossRef]

53. Wang, Q.; Shong, M.; Wang, S. A meta-analysis on the response of microbial biomass, dissolved organic matter, respiration, and $\mathrm{N}$ mineralization in mineral soil to fire in forest ecosystems. For. Ecol. Manag. 2012, 271, 91-97. [CrossRef]

54. De Marco, A.; Gentile, A.E.; Arena, C.; De Santo, A.V. Organic matter, nutrient content and biological activity in burned and unburned soils of a Meditarrenean Maqui area of southern Italy. Int. J. Wildl. Fire 2005, 14, 365-377. [CrossRef]

55. Garcia-Méndez, G.; Maass, J.M.; Matson, P.A.; Vitousek, P.M. Nitrogen transformations and nitrous oxide flux in a tropical deciduous forest in México. Oecologia 1991, 88, 362-366. [CrossRef] [PubMed]

56. Schmidt, M.W.I.; Noack, A.G. Black carbon in soils and sediments: Analysis, distribution, implications, and current challenge. Glob. Biogeochem. Cycles 2000, 14, 777-793. [CrossRef]

57. Ketterings, Q.M.; Birgham, J.M. Soil colour as an indicators of slash-and-burn severity and soil fertility in Sumatra, Indonesia. Soil Sci. Soc. Am. J. 2000, 64, 1826-1833. [CrossRef]

58. Ellingson, L.J.; Kauffman, J.B.; Cummings, D.L.; Sanford, R.L.; Jaramillo, V.J. Soil N dynamics associated with deforestation, biomass burning and pasture conversion in a Mexican tropical dry forest. For. Ecol. Manag. 2000, 137, 41-51. [CrossRef]

59. Giardina, C.P.; Sanford, R.L.; Dockersmith, I.C. Changes in soil phosphorus and nitrogen during slash-and-burn clearing of a dry tropical forest. Soil Sci. Soc. Am. J. 2000, 64, 399-405. [CrossRef]

60. Hammer, E.; Nasr, H.; Wallander, H. Effects of different organic materials and mineral nutrients on arbuscular mycorrhizal fungal growth in a Mediterranean saline dryland. Soil Biol. Biochem. 2011, 43, 2332-2337. [CrossRef]

61. Olsson, P.A.; Jakobsen, I.; Bååth, E.; Söderström, B. The use of phospholipid and neutral lipid fatty acids to estimate biomass of arbuscular mycorrhizal fungi in soil. Mycol. Res. 1995, 99, 623-629. [CrossRef]

62. D'Ascoli, R.; Rutigliano, F.A.; De Pascale, R.A.; Gentile, A.; Virzo De Santo, A. Functional diversity of microbial community in Mediterranean maquis soils as affected by fires. Int. J. Wildl. Fire 2005, 14, 355-363. [CrossRef]

63. Rutigliano, F.A.; De Marco, A.; D’Ascoli, A.R.; Castaldi, S.; Gentile, A.; Virzo De Santo, A. Impact of fire on fungal abundance and microbial efficiency on $\mathrm{C}$ assimilation and mineralization in a Mediterranean maquis soil. Biol. Fert. Soils 2007, 44, 377-381. [CrossRef]

64. Ginzburg, O.; Steinberger, Y. Effects of forest wildfire on soil microbial-community activity and chemical components on a temporal-seasonal scale. Plant Soil. 2012, 360, 243-257. [CrossRef] 
65. Leckie, S.E.; Prescott, C.E.; Grayston, S.J.; Neufeld, J.D.; Mohn, W.W. Characterization of humus microbial communities in adjacent forest types that differ in nitrogen availability. Microbial. Ecol. 2004, 48, $29-40$. [CrossRef] [PubMed]

66. Zhang, Y.; Guo, L.D.; Liu, R.J. Survey of arbuscular mycorrhizal fungi in deforested and natural forest land in the subtropical region of Dujiangyan, southwest China. Plant Soil 2004, 261, 257-263. [CrossRef]

67. Sene, G.; Samba-Mbaye, R.; Thiao, M.; Khasa, D.; Kane, A.; Manga, A.; Samba-Mbaye, M.; Sylla, S.N. The abundance and diversity of legume-nodulation rhizobia and arbuscular mycorrhizal fungal communities in soil samples from deforested and man-made forests systems in a semiarid Sahel region in Senegal. Eur. J. Soil Biol. 2012, 52, 30-40. [CrossRef]

68. Korb, J.E.; Johnson, N.C.; Covington, W.W. Arbuscular mycorrhizal propagule densities respond rapidly to ponderosa pine restoration treatments. J. Appl. Ecol. 2000, 40, 101-111. [CrossRef]

69. Rosendahl, S. Communities, populations and individuals of arbuscular mycorrhizal fungi. New Phytol. 2008, 178, 253-266. [CrossRef] [PubMed]

70. Pattinson, G.S.; Hammill, K.A.; Sutton, B.G.; McGee, P.A. Simulated fire reduces the density of arbuscular mycorrhizal fungi at the soil surface. Mycol. Res. 1999, 103, 491-496. [CrossRef]

71. Azul, A.M.; Ramos, V.; Sales, F. Early effects of fire on herbaceous vegetation and mycorrhizal symbiosis in high altitude grasslands of Natural Park of Estrela Mountain (PNSE). Symbiosis 2010, 52, 113-123. [CrossRef]

(C) 2018 by the authors. Licensee MDPI, Basel, Switzerland. This article is an open access article distributed under the terms and conditions of the Creative Commons Attribution (CC BY) license (http:/ / creativecommons.org/licenses/by/4.0/). 